\title{
PENGENDALIAN PRE-PROJECT SELLING MELALUI PRINSIP PERLINDUNGAN KONSUMEN BERDASARKAN UU NOMOR 8 TAHUN 1999 TENTANG PERLINDUNGAN KONSUMEN
}

\author{
Edi Krisharyanto \\ Fakultas Hukum Universitas Wijaya Kusuma Surabaya \\ e-mail: edikrisharyanto@yahoo.co.id \\ Peni Jati Setyowati \\ Fakultas Hukum Universitas Wijaya Kusuma Surabaya \\ e-mail: penijati.fh@uwks.ac.id
}

\begin{abstract}
ABSTRAK
Pre-Project Selling merupakan suatu perikatan yang dilakukan oleh para pihak terhadap jual beli properti sebelum proyek dibangun dan yang dijual baru berupa gambar atau konsep. Alasan pengembang melakukan praktik Pre-Project Selling ini dalah untuk mengetahui respon pasar atas produk properti yang akan dibangun. Sesuai dengan syarat sahnya perjanjian dalam pasal 1320 Burgerlijk Wetboek dinyatakan bahwa salah satu syarat yang harus dipenuhi adalah adanya objek perjanjian yang jelas. Praktik PreProject Selling merupakan perjanjian khusus. Hal ini disebabkan karena objek perjanjian merupakan gambar atau konsep dari pengembang. Maraknya Pre-Project Selling ini tentu menghadirkan beberapa problematika. Salah satunya adalah mengenai perlindungan konsumen dari gambar atau konsep yang diajukan oleh Pengembang. Dalam penelitian ini akan membahas Pengendalian Pre-Project Selling Melalui Prinsip Perlindungan Konsumen Berdasarkan Undang-Undang Nomor 8 Tahun 1999 tentang Perlindungan Konsumen. Jenis penelitian yang digunakan adalah penelitian normatif, yaitu penelitian yang berdasarkan pada kajian yang sesuai dengan teori dan aturan hukum yang telah ditetapkan. Penelitian normatif ini juga berfungsi untuk memberikan argumentasi secara yuridis terhadap terjadinya kekosongan, kekaburan, dan konflik norma. Dengan demikian penelitian ini dirasa sangat penting sebagai bahan masukan kebijakan agar memeberikan nilai keadilan bagi masyarakat.
\end{abstract}

Kata Kunci: Perlindungan Konsumen; Pre-Project Selling

\section{ABSTRACT}

Pre-Project Selling is an agreement made by the parties to the sale and purchase of properti before the project is built and the new one is sold in the form of pictures or concepts. The reason developers develop this Pre-Project Selling practice is to find out the market's response to the properti product that will be built (test the water). In accordance with the legal conditions of the agreement in article 1320 Burgerlijk Wetboek stated that one of the conditions that must be met is the existence of a clear object of the agreement. The Pre-Project Selling practice is a special agreement. This is because the object of the agreement is an image or concept from the developer. The rise of the Pre-Project Selling certainly presents some problems. One of them is about protecting consumers from images or concepts proposed by Developers. In this study will discuss the Urgency of Consumer Protection against Pre-Project Selling practices that refer to the legal principles in the Consumer Protection Act. This type of research is normative research, which is research based on studies that are in accordance with the theories and legal rules that have been determined. This normative research also functions to provide a juridical argument against the occurrence of emptiness, obscurity, and norm conflicts. Thus this research is considered very important as a policy input material in order to provide the value of justice for the community.

Keywords: Consumer Protection; Pre-Project Selling 


\section{PENDAHULUAN}

Perkembangan pembangunan perumahan dan properti pada beberapa tahun terakhir ini menimbulkan maraknya persaingan yang sangat ketat bagi pengembang atau pengusaha developer dalam menarik pembeli. Persaingan di antara para pengembang atau pengusaha developer ini berdampak pada lahirnya cara-cara praktis dan cepat untuk menjual perumahan atau properti, diantaranya: perkantoran, perumahan maupun apartemen atau rumah susun oleh para pengusaha dengan sistem penjualan Pre-Project Selling.

Pre Project Selling (selanjutnya disebut PPS) merupakan salah satu strategi pemasaran para pengembang, dengan tujuan utama yaitu pendapatan dana guna modal pembangunan dan keuntungan. Cara dari PPS ini dalah dengan penawaran unit hunian berdasarkan brosur yang berisi mengenai konsep hunian, rancang bangun, luas hunian, lokasi hunian, letak strategis hunian, dan lain sebagainya. ${ }^{1}$

Konsep PPS yang dilakukan dengan praktik pemasaran melalui gambar atau konsep ini semakin menjadi marak, terutama bagi para pengembang atau pengusaha developer proyek pemukiman. Penjualan atau pemasaran dilakukan sebelum produk properti yang bersangkutan terwujud. Pada beberapa proyek, terdapat pula pengembang atau pengusaha developer proyek yang melakukan konsep pemasaran PPS sebelum dilengkapi persyaratan antara lain: Izin Mendirikan Bangunan, Izin Konstruksi, dan izinizin lainnya.

Dalam praktiknya, PPS merupakan suatu proses yang dilakukan penjual atau pengusaha developer untuk mengetahui bagaimana minat dan reaksi konsumen terhadap produk properti yang diperjualbelikan. Dalam perkembangannya, tes pasar yang semula tertutup, kemudian dalam praktek di masyarakat dibuat terbuka dan dimanfaatkan langsung oleh pengembang. Hadirnya konsep penjualan PPS ini diharapkan dapat menjual secepat dan sebanyak mungkin.

Daya tarik konsep pemasaran PPS bagi masyarakat in sangat besar jika dilihat dari reaksi konsumen atau orang-orang yang mengunjungi acara

\footnotetext{
${ }^{1}$ Fani Martiawan Kumara Putra. (2019). "Urgensi Batasan Atau Pengendalian Asas Kebebasan Berkontrak Pada Peristiwa Pre Project Selling." Jurnal Perspektif. Volume 24 Nomor 1 Tahun 2019. Surabaya: Universitas Wijaya Kusuma Surabaya, h. 31 .
}

pameran berkaitan dengan pre launching atau pro sale. Pada umumnya, para calon konsumen tergiur dengan adanya potongan harga sebesar $15 \%$ sampai dengan $20 \%$ yang diberikan oleh para pengusaha pengembang. Selain itu, para pengusaha pengembang juga memberikan potongan harga tersebut dengan disertai pemberian bonus alat-alat elektornik yang besarnya mencapai beberapa jutaan rupiah bahkan puluhan juta rupiah.

Dalam praktek pemasaran dengan metode PPS, para calon konsumen harus teliti dulu sebelum melakukan pembelian terhadap properti yang diperjualbelikan sesuai dengan nasihat yang terkesan klise. Bagi calon konsumen atau pembeli rumah, nasihat ini harus diperhatikan, sehingga mereka harus benar-benar mengetahui mengenai siapa pengembang, kualitas bangunan dan riwayat proyek yang telah dilakukan oleh para pengembang. Calon pembeli hanya diyakini melalui brosur, maket, rumah contoh dan penawaran staf pemasaran yang berpenampilan menarik, padahal jelas sekali produknya masih berupa konsep. Daya tarik yang diberikan tersebut bukan hanya berkisar pada hadiah atau pun potongan harga yang diberikan namun banyak digunakan para masyarakat konsumen.

Dalam praktiknya, Konsep PPS banyak pula menimbulkan permasalahan. Salah satunya mengenai kepastian hukum dan perlindungan konsumen terhadap praktik jual beli properti atau pemukiman yang merupakan objek transaksi dan hanya masih berupa konsep. Berdasarkan Undang-Undang Nomor 8 Tahun 1999 tentang Perlindungan Konsumen menjelaskan bahwa hak konsumen diantaranya adalah:

1. hak atas kenyamanan, keamanan, dan keselamatan dalam mengonsumsi barang dan atau jasa;

2. hak untuk memilih barang dan atau jasa serta mendapatkan barang dan atau jasa tersebut.

Berdasarkan uraian tersebut di atas, maka permasalahan yang akan dikaji dalam penelitian ini adalah Pengendalian PPS melalui prinsip perlindungan konsumen berdasarkan UndangUndang Nomor 8 Tahun 1999 tentang Perlindungan Konsumen. 


\section{PEMBAHASAN}

PPS merupakan proses jual beli sebelum proyek dibangun di mana properti yang dijual oleh pengusaha developer tersebut hanya berupa gambar atau konsep. Dalam pelaksanaan di Indonesia, PPS dilakukan penyesuaian, sehingga terdapat beberapa pengembang proyek yang melaksanakan PPS sebelum prasarana dan sarana dibangun, tetapi ada juga yang memasarkan setelah sarana dan prasarana tersebut telah dibangun.

Namun dalam praktiknya PPS lebih sering dilakukan sebelum izin diterbitkan. Hal ini tentu saja tidak hanya melanggar undang-undang, tetapi juga berpotensi menempatkan calon konsumen dalam situasi yang penuh risiko dan terjadinya wanprestasi (prestasi buruk), berupa: ${ }^{2}$

1. tidak terlaksananya apa yang diperjanjikan;

2. terlaksana tetapi tidak tepat waktu (terlambat);

3. terlaksana tetapi tidak seperti yang diperjanjikan; dan

4. dilaksanakan akan tetapi menurut perjanjian tidak boleh dilakukan.

Berbicara mengenai dasar hukum pada konsep PPS tidak lepas dari beberapa peraturan, yaitu: Burgerlijk Wetboek, Undang-Undang No. 1 Tahun 2011 tentang Perumahan dan Kawasan Pemukiman, Undang-Undang No. 20 Tahun 2011 tentang Rumah Susun, dan Undang-Undang No. 8 Tahun 1999 tentang Perlindungan Konsumen. Dari beberapa undang-undang tersebut yang seringkali digunakan pedoman untuk proses PPS adalah Undang-Undang No. 1 Tahun 2011 dan UndangUndang No. 20 Tahun 2011 yang mengatur secara umum tentang pembangunan rumah.

Berdasarkan Pasal 42 ayat (1) Undang-Undang No. 1 Tahun 2011 dinyatakan bahwa dalam Proses PPS menggunakan Perjanjian Pendahuluan. Selain itu, dalam Pasal 42 ayat (3) Undang-Undang No. 20 Tahun 2011 dinyatakan bahwa dalam proses PPS menggunakan Perjanjian Bersyarat. PPS adalah menjual suatu proyek atau bangunan yang obyeknya akan ada di masa mendatang. Dalam hal ini, ketika pengusaha developer melakukan pemasaran, produk yang dipasarkan tersebut belum ada dan hanya berupa

\footnotetext{
${ }^{2}$ Luthvi Febryka Nola. (2017). "Permasalahan Hukum dalam Pre-Project Selling." Majalah Info Singkat Hukum. Vol. IX No. 18/II/Puslit/September/2017.
}

brosur-brosur atau iklan penawaran, maka pelaku pembangunan sekurang-kurangnya harus memiliki: ${ }^{3}$

a. Kepastian peruntukkan ruang;

b. Kepastian hak atas tanah;

c. Kepastian status penguasaan rumah susun;

d. Perizinan pembangunan rumah susun;

e. Jaminan atas pembangunan rumah susun dari lembaga penjamin.

Menurut Sri Soedewi Masjchoen Sofwan, berpendapat bahwa perjanjian merupakan perbuatan hukum dimana seseorang atau lebih mengikatkan dirinya terhadap seorang lain atau lebih. ${ }^{4}$ Para pihak diberikan kebebasan untuk membuat isi perjanjian yang mereka sepakat untuk menjadi pengaplikasian asas kebebasan berkontrak. Namun kebebasan tersebut dibatasi oleh pengaturan dalam Pasal 1337 Burgerlijk Wetboek yang menghendaki suatu perjanjian itu tidak boleh bertentangan dengan asas kesusilaan dan ketertiban umum. Selain itu dalam praktik PPS juga harus tetap berpedoman pada Pasal 1320 Burgerlijk Wetboek yang menentukan bahwa untuk sahnya suatu perjanjian diperlukan empat syarat yaitu:

1. Sepakat mereka yang mengikat dirinya;

2. Kecakapan untuk membuat suatu perikatan;

3. Suatu hal tertentu;

4. Suatu sebab yang diperbolehkan.

Unsur esensial dari perjanjian pengikatan jual beli adalah barang dan harga. Para pihak yang berkepentingan dalam perjanjian jual beli mengikatkan dirinya terhadap barang dan harga dengan kesepakatan yang telah disepakatinya. Perjanjian pengikatan jual beli merupakan perjanjian dengan asas konsensualisme. ${ }^{5}$ Dalam pelaksanaan PPS, R. Subekti menyatakan, bahwa perjanjian pengikatan jual beli adalah perjanjian antar pihak penjual dan pihak pembeli sebelum dilaksanakannya jual beli dikarenakan adanya unsur-unsur yang harus dipenuhi untuk jual beli tersebut, antara lain sertifikat hak atas tanah belum ada karena masih dalam proses,

\footnotetext{
${ }^{3}$ Urip Santoso. (2014). Hukum Perumahan. Jakarta: Kencana, h. 428.

4 Sri Soedewi Masjchoen. (2007). Hukum Jaminan di Indonesia, Pokok-Pokok Hukum Jaminan dan Jaminan Perorangan. Yogyakarta: Liberty, h. 1.

${ }^{5}$ J. Andy Hartanto. (2012). "Karakteristik Hak Milik Atas Satuan Rumah Susun di Indonesia dan Peralihannya." Disertasi. Surabaya: Fakultas Hukum Universitas Airlangga, h. 15.
} 
atau belum terjadinya pelunasan harga. ${ }^{6}$ Oleh sebab itu dalam PPS terdapat 2 (dua) perjanjian yaitu Perjanjian Pengikatan Jual Beli dan Perjanjian Jual Beli.

Dalam PPS, Surat Pemesanan (selanjutnya disebut SP) merupakan surat yang berisi pemesanan rumah bagi masyarakat yang serius ingin membeli. SP ini merupakan transaksi awal sebab setelah calon pembeli menandatanganinya dan harus melakukan pembayaran terhadap biaya-biaya seperti biaya pemesanan (booking fee) dan uang muka (down payment/DP). Selain itu, calon pembeli harus tunduk dan terikat pula dengan syarat dan ketentuan dalam SP tersebut. Selanjutnya, setelah pembeli membayar sejumlah harga tertentu (biasanya $30 \%$ (tiga puluh persen) dari harga rumah), maka dilakukan Perjanjian Pengikatan Jual Beli (PPJB). PPJB tersebut ditandatangani oleh para pihak dihadapan para saksi-saksi. Pada saat penandatangan PPJB, biasanya calon konsumen/pembeli diberikan kesempatan untuk membaca dan mempelajari draft PPJB terlebih dahulu dengan dipandu "petugas pembaca PPJB" dari pihak pengembang. Draft PPJB yang diberikan, pada umumnya tidak bisa dibawa pulang oleh calon konsumen dan penjelasan yang diberikan oleh pengusaha developer pun hanya sedikit informasi, sehingga banyak calon pembeli yang "terpaksa" asal tanda tangan tanpa memahami substansi PPJB. Padahal, di dalam PPJB tersebut banyak tidak paham mengenai klausul-klausul. Hal ini yang kemudian sering menimbulkan akibat hukum yang cenderung merugikan calon pembeli apabila terjadi permasalahan di kemudian hari.

Bila dilihat dari fungsinya, maka seyogyanya PPJB yang merupakan perjanjian pendahuluan untuk lahirnya perjanjian pokok, yaitu biasanya isinya berupa janji-janji dari para pihak yang mengandung ketentuan tentang syarat-syarat yang disepakati untuk sahnya melakukan perjanjian utamanya. Misalnya dalam perjanjian jual beli terhadap hak atas tanah, maka dalam perjanjian pengikatan jual beli ini pada umumnya berisi mengenai janji-janji baik dari pihak penjual maupun dari pihak pembelin tentang pemenuhan terhadap syarat-syarat dalam

${ }^{6}$ R. Subekti. (2016). “Aspek-Aspek Hukum Perikatan Nasional", dikutip dari Supriyadi. (2016). "Kedudukan Perjanjian Pengikatan Jual Beli Hak Atas Tanah dalam Perspektif Hukum Pertanahan." Jurnal Arena Hukum. Edisi No. 2 Vol. 9. Badan Pertanahan Nasional Mataram, h. 205. perjanjian jual beli. Hal ini perlu dilakukan agar para pihak dapat menandatangan perjanjian utama, yaitu perjanjian jual beli dan akta jual beli di hadapan Pejabat Pembuat Akta Tanah (PPAT). Kemudian seperti janji dalam melakukan pengurusan sertifikat tanah, sebelum jual beli dilakukan sebagaimana diminta oleh pihak pembeli, atau janji untuk segera melakukan pembayaran oleh pembeli sebagai syarat dari penjual, sehingga akta jual beli dapat di tandatangani di hadapan Pejabat Pembuat Akta Tanah (PPAT).

Konsep pemasaran PPS ini memang sangat menguntungkan penjual (developer) karena beban investasi yang harus ditanggungnya untuk pembangunan konstruksi proyek tersebut terbantu oleh dari adanya dana pesanan yang berasal dari dana calon konsumen atau pembeli. Dengan adanya pesanan ini juga dapat mempermudah perusahaan, karena pengembang tidak perlu menyediakan modal pengembangan di depan untuk biaya pembangunan yang cukup besar. Selain itu keadaan pasar juga sudah pasti sehingga unsur spekulasinya lebih kecil. Dalam hal ini terdapat kepercayaan antara penjual (pengembang) dan pembeli, yaitu pengembang percaya bahwa konsumen akan melunasi pembayaran yang disepakati sesuai dengan jadwal.

Hubungan hukum antara calon pembeli dengan pengembang dilandasi oleh perjanjian jual beli. Dalam hal ini pihak penjual (pengembang) berkedudukan sebagai penyedia perumahan dan konsumen sebagai pembeli. Bank sebagai penerima kuasa dari calon pembeli merupakan mitra dari pengembang. Berkaitan dengan akibat hukum yang lahir dari adanya hubungan hukum, maka akan muncul apabila salah satu para pihak tidak menjalankan kewajibannya dengan baik. Apabila hal ini terjadi, maka calon pembeli dapat melakukan komplain. Komplain juga akan terjadi apabila hasil yang diterima tidak sesuai dengan perjanjian yang telah disepakati pada saat transaksi jual beli yang dilakukan. Dalam suatu perjanjian, apabila pelaku usaha dapat menyelesaikan kewajibannya dengan baik sesuai dengan yang disepakati dalam perjanjian, maka pelaku usaha telah melakukan prestasi (kewajiban). Namun apabila pelaku usaha telah lalai dan tidak dapat menyelesaikan prestasi (kewajiban) dengan baik, maka akan timbul suatu wanprestasi. 
Edi Krisharyanto dan Peni Jati Setyowati,

Pengendalian Pre-Project Selling Melalui Prinsip Perlindungan Konsumen Berdasarkan UU Nomor 8 Tahun 1999 tentang Perlindungan Konsumen

Wanprestasi atau cidera janji adalah tidak terlaksananya prestasi atau kewajiban sebagaimana yang telah disepakati di dalam kontrak. Tindakan wanprestasi ini membawa konsekuensi timbulnya hak dari pihak yang dirugikan dan menuntut pihak yang melakukan wanprestasi untuk memberikan ganti rugi atau penggantian. Ada tiga macam bentuk wanprestasi yaitu:

1. wanprestasi tidak memenuhi prestasi;

2. wanprestasi terlambat memenuhi prestasi; dan

3. wanprestasi tidak sempurna memenuhi prestasi.

Di samping adanya hak dan kewajiban yang perlu diperhatikan oleh pengembang (pelaku usaha), maka terdapat pula tanggung jawab (responsibility) yang harus dipikul oleh pihak pengusaha developer sebagai bagian dari kewajiban yang mengikat kegiatannya dalam usaha PPS. Dalam terjadinya kondisi ini, maka diharapkan ada kewajiban dari pihak pengusaha developer untuk selalu bersikap waspada dan hatihati dalam menerbitkan data dan informasi yang ada di dalam brosur kepada konsumen.

Menurut Shidarta, ${ }^{7}$ perlindungan konsumen adalah segala upaya yang menjamin adanya kepastian hukum untuk memberikan perlindungan kepada konsumen. Kepastian hukum untuk memberikan perlindungan kepada konsumen itu ditujukan untuk meningkatkan harkat dan martabat konsumen serta memberikan akses informasi tentang suatu produk.

Dalam kaitannya perlindungan konsumen pada transaksi PPS, berdasarkan Undang-Undang No. 8 Tahun 1999 tentang Perlindungan Konsumen, maka terdapat beberapa asas yang harus diperhatikan, yaitu: perlindungan konsumen berasaskan manfaat, keadilan, keseimbangan, keamanan dan keselamatan konsumen, serta kepastian hukum. Dalam hal ini, kepastian hukum ini meliputi segala aspek dan upaya berdasarkan hukum untuk memberdayakan calon pembeli memperoleh atau menentukan pilihannya atas barang dan atau jasa kebutuhannya serta mempertahankan atau membela hak-haknya apabila dirugikan oleh pelaku usaha penyedia kebutuhan konsumen tersebut.

Asas manfaat dalam UU Perlindungan Konsumen dimaksudkan untuk mengamanatkan bahwa segala upaya dalam penyelenggaraan perlindungan konsumen harus memberikan manfaat

7 Shidarta. (2000). Hukum Perlindungan Konsumen Indonesia. Jakarta: Grasindo, h. 136. sebesar-besarnya bagi kepentingan konsumen dan pelaku usaha secara keseluruhan (Penjelasan Pasal 2 Undang-Undang Perlindungan Konsumen). Segala upaya dalam perlindungan konsumen terhadap PPS hendaknya senantiasa memberikan manfaat bagi para pihak (pengusaha dan calon pembeli). Bagi calon pembeli, pemberlakuan UU Perlindungan Konsumen yang mengatur mengenai hak dan kewajiban telah mempertegas posisinya sebagai konsumen yang dilindungi oleh hukum. Selain itu, pemberlakuan UU Perlindungan Konsumen juga telah memberikan kemudahan-kemudahan bagi konsumen untuk menuntut haknya (calon pembeli) apabila dirugikan oleh pelaku usaha.

Berbeda halnya dengan pemberlakuan UU Perlindungan Konsumen bagi pengusaha developer. Bagi pengusaha developer, tidak dimaksudkan untuk mematikan kegiatan usaha pelaku usaha, namun justru ingin menciptkan perlindungan konsumen dan dapat mendorong iklim berusaha yang sehat khususnya bisnis dengan PPS. Asas keadilan dengan asas ini melalui bisnis dengan sistem PPS. dimaksudkan agar adanya partisipasi dari seluruh rakyat dapat diwujudkan secara maksimal dan memberikan kesempatan bagi para pihak untuk memperoleh haknya dan melaksanakan kewajibannya secara adil.

Asas keseimbangan dalam PPS dimaksudkan untuk memberikan keseimbangan antara kepentingan konsumen, pelaku usaha dan pemerintah dalam arti materiil dan spiritual, sehingga dalam usaha ini tidak mengejar kekayaan duniawi tapi juga untuk melindungi kepentingan rohani yang perlu diperhatikan dan kepentingan stakeholder lainnya.

Asas keamanan dan keselamatan dalam PPS dimaksudkan untuk memberikan jaminan atas keamanan konsumen dan keselamatan kepada konsumen dalam penggunaan, pemakaian, dan pemanfaatan barang dan/atau jasa yang digunakan konsumen, maka melalui bisnis dengan PPS ini pelaku usaha memulai usaha tetap memperhatikan faktor keamanan dan keselamatan konsumen.

Asas kepastian hukum dalam PPS dimaksudkan agar para pihak (calon pembeli dan pengusaha developer) dapat menaati hukum dan memperoleh keadilan dalam penyelenggaraan perlindungan konsumen. Selain itu, Negara dalam hal ini Pemerintah, dapat menjamin kepastian hukum terhadap pelaksanaan PPS. Oleh sebab itu para pihak 
dalam usaha PPS, mendasarkan setiap usaha dengan berpegang pada prinsip-prinsip tersebut, dari prinsip inilah akan menjadi acuan dasar untuk memulai usaha, menjalankan usaha sampai akhir kontrak dari usaha tersebut. Hal ini sangat penting bagi keberlangsungan usaha dan perlindungan hukum para pihak. Posisi konsumen yang lemah harus dilindungi oleh hukum. Salah satu sifat dan tujuan hukum adalah dapat memberikan perlindungan atau pengayoman kepada masyarakat.

Berdasarkan UU Perlindungan Konsumen menetapkan 9 (sembilan) hak konsumen, yaitu:

a. Hak atas kenyamanan, keamanan, dan keselamatan dalam mengkonsumsi barang dan/ atau jasa;

b. Hak untuk memilih barang dan/jasa serta mendapatkan barang dan/atau jasa tersebut sesuai dengan nilai tukar dan kondisi serta jaminan yang dijanjikan;

c. Hak atas informasi yang benar, jelas, dan jujur mengenai kondisi dan jaminan barang dan/atau jasa;

d. Hak untuk didengar pendapat dan keluhannya atas barang dan/atau jasa yang digunakan;

e. Hak untuk mendapatkan advokasi perlindungan konsumen secara patut;

f. Hak untuk mendapatkan pembinaan dan pendidikan konsumen;

g. Hak untuk diperlakukan atau dilayani secara benar dan jujur sertatidak diskriminatif;

h. Hak untuk mendapatkan konpensasi, ganti rugi dan/atau penggantian, apabila barang dan/atau jasa yang diterima tidak sesuai dengan perjanjian atau tidak sebagaimana mestinya;

i. Hak-hak yang diatur dalam ketentuan peraturan perundang-undangan lainnya

Dalam kaitannya PPS, maka seyogyanya terdapat kepastian hukum dan perlindungan hukum kepada calon pembeli diharapkan juga mampu meningkatkan kesadaran, kemampuan dan kemandiriannya dalam melindungi diri sendiri sehingga mampu mengangkat harkat dan martabat calon pembeli dengan menghindari berbagai akses negatif yang berkaitan dengan PPS.

\section{PENUTUP}

\section{Kesimpulan}

PPS dalam perkembangan jual beli properti wajib melindungi hak-hak pembeli dengan berlandaskan pada prinsip-prinsip perlindungan konsumen yang ada berdasarkan UU Perlindungan Konsumen. Perlindungan hak pembeli perlu dilakukan untuk menghindari terjadinya sengketa dan gugatan berkaitan dengan proses jual beli properti. Oleh karenanya, asas kebebasan berkontrak dalam perjanjian jual beli melalui PPS juga wajib dibatasi untuk melindungi hak-hak pembeli.

\section{Rekomendasi}

Perkara ada cidera dalam bentuk sosialisasi yang rutin, dalam bentuk apapun dari pemerintah untuk menyadarkan para calon pembeli PPS atas hakhaknya, sehingga dapat mengatasi sengketa-sengketa yang ada atas dasar penjualan dengan metode PPS.

\section{DAFTAR PUSTAKA}

Peraturan Perundang-undangan:

Undang-Undang Nomor 8 Tahun 1999 tentang Perlindungan Konsumen.

Undang-Undang Nomor 1 Tahun 2011 tentang Perumahan dan Kawasan Pemukiman.

Undang-Undang Nomor 20 Tahun 2011 tentang Rumah Susun.

Burgerlijk Wetboek.

\section{Buku:}

Shidarta. (2000). Hukum Perlindungan Konsumen Indonesia. Jakarta: Grasindo.

Urip Santoso. (2014). Hukum Perumahan. Jakarta: Kencana.

\section{Jurnal:}

Ahmadi Miru. (2000). "Prinsip-prinsip Perlindungan Hukum Bagi Konsumen di Indonesia”. Disertasi. Surabaya: Program Pascasarjana Universitas Airlangga.

Fani Martiawan Kumara Putra. (2019). "Urgensi Batasan Atau Pengendalian Asas Kebebasan Berkontrak Pada Peristiwa Pre Project Selling." Jurnal Perspektif. Volume 24 Nomor 1 Tahun 2019. Surabaya: Universitas Wijaya Kusuma Surabaya, h. 31. 
Edi Krisharyanto dan Peni Jati Setyowati,

Pengendalian Pre-Project Selling Melalui Prinsip Perlindungan Konsumen Berdasarkan UU Nomor 8 Tahun 1999 tentang Perlindungan Konsumen

J. Andy Hartanto. (2012). "Karakteristik Hak Milik Atas Satuan Rumah Susun di Indonesia dan Peralihannya." Disertasi. Surabaya: Fakultas Hukum Universitas Airlangga.

Luthvi Febryka Nola. (2017). "Permasalahan Hukum dalam Pre-Project Selling." Majalah Info Singkat Hukum. Vol. IX No. 18/II/Puslit/ September/2017.
R. Subekti. (2016). “Aspek-Aspek Hukum Perikatan Nasional”, dikutip dari Supriyadi. (2016). "Kedudukan Perjanjian Pengikatan Jual Beli Hak Atas Tanah dalam Perspektif Hukum Pertanahan." Jurnal Arena Hukum. Edisi No. 2 Vol. 9. Badan Pertanahan Nasional Mataram. 